\title{
CONSTRUÇÃO HISTÓRICA DA CONTENÇÃO DO PODER PUNITIVO: dos primórdios ao Direito Penal liberal
}

\section{BUILDING HISTORIC PUNITIVE POWER RETENTION : the beginnings of liberal criminal law}

Fabio Roque da Silva Araújo ${ }^{1}$

\begin{abstract}
Resumo: O presente trabalho tem por objetivo analisar historicamente os comportamento e ações sociais considerados desviantes, desde as mais rudimentares sociedades até a contemporaneidade, na tentativa de encontrar os fundamentos da contenção do poder punitivo com o intuito de enfrentar o totalitarismo, questão que intriga e aflige tantos quantos se debruçaram sobre as razões de existência do Direito Penal. Sem a pretensão de exaurir as discussões, objetiva apontar as bases históricas que conduziram à construção da contenção do poder punitivo do Estado Moderno, cujo ápice foi materializado no ideal iluminista, que traz consigo o Direito Penal liberal.
\end{abstract}

\section{Palavras-chave: CONTEXTO HISTÓRICO. PODER PUNITIVO. MONOPÓLIO. DIREITO PENAL}

Abstract: This study aims to historically analyze the behavior and social activities considered deviant, from the most rudimentary societies to contemporary times, trying to find the foundations of containment of punitive power in order to confront totalitarianism, question that intrigues and afflicts so many how many have studied the reasons for the existence of criminal law. Without claiming to exhaust the discussions, aims to point out the historical basis which led to the construction of the containment of the punitive power of the modern state, whose summit was embodied in the Enlightenment ideal that brings the Criminal Law liberal.

Keywords: HISTORICAL CONTEXT. PUNITIVE POWER. MONOPOLY. TORT LAW

\footnotetext{
${ }^{1}$ Mestre e Doutorando em Direito Público pela Universidade Federal da Bahia. Professor da Faculdade Baiana de Direito, da Escola de Magistrados da Bahia (EMAB) e do curso JusPODIVM/BA. Professor convidado dos cursos de Especialização em Ciências Criminais da Fundação Faculdade de Direito da UFBa e do curso Praetorium/MG. Professor-Coordenador do curso de Especialização em Direito Penal e Processo Penal da EMAB. É Juiz Federal/BA. Ex- Juiz de Direito. Ex-Procurador Federal.
} 


\section{Introdução}

Não se tem notícia histórica da existência de sociedade em que os comportamentos considerados desviantes não estivessem presentes. Mesmo nas organizações sociais mais rudimentares, os homens estabeleceram certas regras de convivência, seja com o intuito de manter a coesão do grupo social, seja como forma de se defender de eventuais excessos perpetrados por demais membros do grupo. Uma vez estabelecidas as regras de convivência, as respectivas violações - os comportamentos desviantes - sempre estiveram presentes, em maior ou menor monta.

Desde as mais primitivas formas de organização social, o homem convive com fórmulas de retaliação a estes comportamentos considerados desviantes. Seja por meio de represálias oriundas de particulares, seja por meio de punições emanadas do poder constituído pelo grupo social, as punições são uma constante na história da humanidade.

Encontrar os fundamentos da contenção deste poder punitivo - sob pena de se descambar para o mais abjeto totalitarismo - é a questão que intriga e aflige tantos quantos se debruçaram sobre as razões de existência do Direito Penal.

Estabelecidas estas premissas, cumpre asseverar que o presente trabalho, sem pretensões de exaurir as discussões, objetiva apontar as bases históricas que conduziram à construção da contenção do poder punitivo do Estado Moderno, cujo ápice foi materializado no ideal iluminista, que traz consigo o Direito Penal liberal. .

\section{As vinganças}

As primeiras notícias históricas acerca do Direito Penal apontam para a sua estreita relação com as vinganças que se desenvolviam nas comunidades da Idade Antiga ou, até mesmo, da pré-história.

A rigor, as vinganças penais sequer podem ser consideradas manifestações do Direito Penal, senão como seu embrião, na medida em que coincidem tão-somente no que tange à utilização do poder de punir como forma de resposta aos comportamentos desviantes. No perído earaterizado como hegemônico por parte das vinganças, o comportamento desviante não constituía afronta à ordem jurídica estatal, e sim uma afronta à divindade ou à tribo.

Convencionou-se proceder a uma distinção entre as espécies de vingança, de acordo com o fundamento da punição a ser imposta. Assim, neste período, podem ser 
identificadas, ao menos, três distintas espécies de vingança, a saber: (i) vingança divina; (ii) vingança privada e (iii) vingança pública. Não há uma divisão histórica precisa que delimite cada uma destas fases, havendo, isto sim, períodos históricos com maior ou menor influência de cada um destes tipos de vingança penal.

A primeira espécie de vingança é fruto da forte influência exercida pela religião nos povos da Antiguidade. Neste período, acreditava-se que os fenômenos naturais que traziam algum revés à população decorriam da insatisfação dos deuses, ofendidos com algum comportamento de membros do grupo. Estes fenômenos naturais que acarretavam algum prejuízo à comunidade eram conhecidos como totem $^{2}$, razão pela qual se fala em infração totêmica ${ }^{3}$.

O comportamento desviante não constituía afronta ao indivíduo ou ao grupo social, e sim aos próprios deuses que, como retaliação, lançavam sua ira contra a população, em forma de catástrofes naturais, ou fenômenos naturais mais corriqueiros, como a ausência de chuvas ou as constantes ventanias, empecilhos à produção agrícola ou à atividade pesqueira, fonte de renda das comunidades.

Claro está que a forma de aplacar a ira dos deuses era a promoção da reprimenda em desfavor daquele que havia originado a revolta divina por meio da infração totêmica. Para logo se vê que não havia proporcionalidade entre a infração praticada e a sanção aplicada. Sendo os deuses as "vítimas" da infração, pouco importava que a conduta praticada contivesse mínimo grau de lesividade. A pena obedecia ao critério de veneração da divindade, razão pela qual quanto mais severa fosse, maior o desagravo aos deuses. Outro fato

\footnotetext{
${ }^{2}$ Não se pode deixar de anotar, todavia, que a expressão fora utilizada em diversos sentidos. Assim, afirma-se que a expressão totem foi extraída do idioma dos índios norte-americanos, passando, posteriormente, a indicar o fenômeno de transformação de uma coisa em emblema do grupo social. Por seu turno, Durkheim encarou o totem como a expressão da unidade do grupo social. Levi-Strauss promoveu a redução do totem a um fenômeno lingüístico formal. Por fim, ao discorrer sobre "totem e tabu", Freud valeu-se dos termos para apresentar uma interpretação psicanalítica. (ABBAGNANO, Nicola. Dicionário de filosofia. Tradução da $1^{\circ}$. Edição brasileira coordenada e revista por Alfredo Bosi; revisão da tradução e tradução dos novos textos de Ivone Castilho Benedeti. 5. ed. São Paulo: Martins Fontes, 2007, p.1147).

${ }^{3}$ De acordo com Cláudio Brandão, in verbis: "A pena primitiva era ligada a violação do tabu. Essa palavra, de origem polinésica, significava, a um só tempo, o sagrado e o proibido. Os tabus, enquanto proibições de caráter mágico ou religioso, eram leis dos deuses que não deveriam ser infringidas para não retirar o poder protetor da divindade." (BRANDÃO, Cláudio. Curso de direito penal: parte geral. Rio de Janeiro: Forense, 2008, p.23). Procurando estabelecer uma precisa distinção entre totem e tabu, afirma Geder Luiz Rocha Gomes que, in verbis: "O totem simbolizava a origem do clã, o seu espírito guardião, que preserva a existência daquela coletividade e oferece perigo aos estranhos, cabendo aos membros do clã protegê-lo. O totem representava um animal ou um fenômeno natural, também poderia representar um vegetal. (...). O tabu traduzia-se em uma convenção sagrada, desprovida de racionalidade. Porém fazia parte da própria formação do clã, como um valor transmitido de geração a geração, como um dogma inquestionável.” (GOMES, Geder Luiz Rocha: A substituição da prisão. Alternativas penais: legitimidade e adequação. Salvador: JusPodivm, 2008, p.33).
} 
característico desta época é a aplicação da sanção, que deveria ser levada a cabo pelo sacerdote.

Em suma, o período da vingança divina caracterizou um "direito penal" teocrático e sacerdotal, em que as punições possuíam acentuado grau de severidade, desproporcionais à ofensa praticada, e que tinham na intimidação o seu objetivo maior. A vingança divina marcou uma série de civilizações, podendo-se mencionar, de forma exemplificativa, o Código de Manu, bem como as legislações do Egito (Cinco Livros), da Pérsia (Avesta), de Israel (Pentateuco) e da China (Livro das Cinco Penas) ${ }^{4}$.

Neste período, não há que se falar em critérios de racionalidade ou cientificidade a orientar o Direito Penal. Em decorrência destas características teocráticas e sacerdotais, as punições desta época estão marcadas por uma postura religiosa, no mais das vezes, fruto de crenças e superstições locais.

Consectário da pretensão de desagravar os deuses por intermédio da aplicação da pena, é a sua natureza excessivamente cruel. Sanções como apedrejamento público, penas de enforcamento, de sepultamento com vida nos pântanos ${ }^{5}$, ou o suplício da roda ${ }^{6}$. A despeito da crueldade e do caráter desproporcional, que marcam as sanções nesta época, às transgressões de pouca importância reservavam-se as sanções de natureza moral ou de repúdio ${ }^{7}$.

Este período histórico não conheceu a pena de prisão ${ }^{8}$. Não significa dizer que o encarceramento dos condenados ou daqueles sujeitos a julgamento não ocorressem com frequiência. Porém, a isto se restringia a função da privação de liberdade, isto é, acautelamento, para posterior aplicação das sanções, identificadas, como regra geral, com suplícios e aflições físicas. A prisão-pena surge em momento histórico assaz posterior. .

Ultrapassada a fase das vinganças divinas, houve a consagração das vinganças privadas, que poderiam ser tanto de cunho individual (a revanche da vítima, ou de seus

\footnotetext{
${ }^{4}$ BITENCOURT, Cezar Roberto. Tratado de direito penal: parte geral, volume 1, 10. ed. São Paulo: Saraiva, 2006, p.36.

${ }^{5}$ BRANDÃO, Cláudio. Ob. cit., p.24.

6 "O suplício da roda consistia em prender o corpo do condenado a um apoio para depois dilacerar seus membros com uma grande roda; após o dilaceramento dos membros, prendia-se o corpo ainda vivo na própria roda, para, em seguida, colocá-lo no alto em uma posição elevada. Em um estádio posterior da evolução desse suplício, alguns instrumentos eram utilizados para separar os membros do corpo, como, por exemplo, a marreta e o porrete" (BRANDÃO, Cláudio. Ob. cit., p.24).

${ }^{7}$ FÜHRER, Maximiliano Roberto Ernesto. História do direito penal (crime natural e crime de plástico). São Paulo: Malheiros, 2005, p.24.

8 “Os vestígios que nos chegaram dos povos e civilizações mais antigos (Egito, Pérsia, Babilônia, Grécia, etc) coincidem com as finalidades que se atribuíam primitivamente à prisão: lugar de custódia e tortura" (BITENCOURT, Cezar Roberto. Falência da pena de prisão: causas e alternativas. 3. ed. Saraiva: São Paulo, 2004, p.05).
} 
familiares contra o ofensor) quanto de cunho coletivo, grupal ${ }^{9}$. Freqüente, ainda, a exclusão de um membro do grupo - isto é, o banimento - quando este era o responsável pela infração, no que se convencionou chamar de "perda da paz"

De acordo com Franz von Liszt ${ }^{11}$, a idéia de excomunhão do grupo ressalta, de forma flagrante, o caráter social desta pena primitiva. Em relação àquele que era expulso da coletividade, dizia-se que seria "abandonado aos lobos". Com a aplicação da referida pena, objetiva-se, como conseqüência imediata, o confisco dos bens, o desterro e, também, a perda da honra ${ }^{12}$.

Em contrapartida, se a ofensa partisse de um membro de outro grupo, tal atitude fatalmente ocasionaria a deflagração de uma guerra grupal, a chamada "vingança de sangue". A mola propulsora da aplicação desta pena é o forte sentimento de grupo - seja a tribo, o clã ou a estirpe - vigente nesta época. Durante muito tempo, os membros de uma família estiveram obrigados a vingar o homicídio praticado em desfavor de um dos seus, com a morte de integrantes da família do ofensor. Esta obrigação esteve em voga entre os índios e, também, entre os romanos da cidade antiga ${ }^{13}$.

Com o passar do tempo, e o conseqüente abandono da organização tribal e a acolhida de concepções mais requintadas de organização, o controle social passa a ser exercido pela vingança pública. Ainda não havia que se falar em proporcionalidade entre delito e pena. As sanções eram desproporcionais, extremamente severas, orientadas pela idéia de intimidação e possuíam por característica, sobretudo, a idéia de tutela do soberano.

\section{Manifestações do Direito Penal na Antiguidade}

\footnotetext{
9 Relevante consignar que há certa divergência em relação à identificação desta reação grupal como manifestação de vingança. Neste sentido, ressalta Franz von LISZT que, in verbis: "Por conseguiente, la opinión, muy extendida, que ve la raiz de la pena en el instinto de venganza, manifestandose a través del institnto de conservación de los individuos, requiere rectificación. La expulsión de la associación de la paz como venganza de sangre, no es reacción del individuo, sino reacción de la associación de tribus, como mandataria del orden de la paz y del Derecho" (In: Tratado de derecho penal. Florida: Valletta Ediciones, 2007, p.14).

10 "Perdida a paz, estava o homem exposto à morte, não só porque, rompidos os vínculos mágicos ou de sangue com o clã, ficava à mercê da violência dos outros, mas ainda porque sozinho, no mundo de então, deserto de homens, dificilmente poderia defender-se das forças hostis da natureza, cósmicas ou animais" (BRUNO, Aníbal. Direito penal: parte geral, tomo I. 5. ed. Rio de Janeiro: Forense, 2005, p.33).

${ }^{11}$ In: A idéia do fim no direito penal. Tradução: Hiltomar Martins Oliveira. São Paulo: Rideel, 2005, p.24.

${ }^{12}$ LISZT, Franz von. A idéia do fim no direito penal. Tradução: Hiltomar Martins Oliveira. São Paulo: Rideel, 2005. p.24-25.

${ }^{13}$ FÜHRER, Maximiliano Roberto Ernesto. História do direito penal (crime natural e crime de plástico). São Paulo: Malheiros, 2005, p.24.
} 
As mais diversas culturas conheceram manifestações díspares de Direito Penal. As sutilezas, as peculiaridades de cada civilização, marcaram, de forma significativa, a manifestação do poder de punir, ensejando uma variedade imensa de reprimenda penal.

Para adotar por paradigma as civilizações mais distantes, das quais menos se tem notícia, salutar destacar que o Direito Penal surge no Japão e na Coréia do Sul embasado em uma concepção teocrática ${ }^{14}$. Os primeiros tempos da civilização chinesa assinalam a emergência das cinco penas. As cinco penas consistiam na morte, para o crime de homicídio, a castração para o crime de estupro, a amputação de um ou ambos os pés para os crimes de lesões e de furto, a amputação do nariz para os crimes de fraude e, por fim, e a imposição de uma marca na testa, para os crimes de menor gravidade ${ }^{15}$.

As cinco penas mantiveram-se vigentes até a República, em 1912, muito embora tenham sofrido algumas alterações em seu conteúdo. Contudo, elas conviveram com outras formas de sanções, mais cruéis, inclusive. Como exemplo destas sanções, pode-se mencionar: "abraçar uma coluna de ferro incandescente, esquartejamento, tortura, açoitamento, espancamento, distintas formas de pena de morte, furar os olhos com ferro candente, especialmente, a extensão do castigo à família do autor"16.

Por seu turno, a civilização suméria também possuiu peculiaridades que a distinguiam. Assim, em XXI a.C. o Rei Ur-Nammu editou um conjunto de leis que consagrou o abrandamento da reprimenda penal, prevendo, inclusive, a substituição dos suplícios e mutilações pelo pagamento de multa em favor do ofendido, em delitos como o de injúria ${ }^{17}$. No mais, também foi uma civilização cujo Direito Penal assentou-se em uma concepção teocrática, valendo destacar que havia a hierarquia entre os deuses, razão pela qual a ofensa a determinada divindade deveria ser castigada de forma mais severa.

Como consabido, a civilização do Egito, na Antiguidade, também possuía natureza teocrática, marcada pelo politeísmo, tendo o Faraó como representação da divindade na Terra. Face a esta arraigada postura teocrática, as condutas consideradas atentatórias aos deuses ou ao próprio Faraó mereciam reprimenda severa, em regra a pena de morte, acompanhada, ou não, de tortura.

Desde esta época a humanidade já conhecia a famigerada pena de crucificação, posteriormente acolhida pelo Império Romano. Os egípcios conheceram, também, as penas de

\footnotetext{
${ }^{14}$ ZAFFARONI, Eugênio Raul; PIERANGELI, José Henrique. Manual de direito penal brasileiro - parte geral. 5. ed. São Paulo: Revista dos Tribunais, 2004, p.177.

${ }^{15}$ Idem, p. 176.

${ }^{16}$ ZAFFARONI, Eugênio Raul; PIERANGELI, José Henrique. Ob. cit. p.176.

${ }^{17}$ FÜHRER, Maximiliano Roberto Ernesto. Ob. cit. p.27.
} 
enforcamento, mutilações, desterro, amputação da língua e do nariz, castração, empalação, escravidão e trabalhos forçados. No que toca à escravidão, representou, para o momento histórico, abrandamento das punições aplicadas, tamanho era o grau de sua severidade.

Para os condenados dos grupos sociais mais elevados permitia-se o suicídio, como forma de evitar a execução pública ${ }^{18}$. Este período histórico admitiu, ainda, a utilização da tortura como técnica de investigação, para o descobrimento da verdade.

Legislação penal de bastante relevância foi a indiana, conhecida como código de Manu. A origem do referido código é bastante controversa, não havendo consenso em relação à data em que adveio. O fato é que exerceu impressionante influência na formação da cultura jurídica indiana, sendo certo que muitas de suas disposições são observadas até a atualidade.

Originalmente, o código de Manu foi escrito em sânscrito, em versos, e descrevia condutas consideradas boas e condutas reprováveis, dando conta, inclusive, das conseqüências dos atos praticados pelos homens após a sua morte. De acordo com a tradição indiana, o código foi escrito por Manu, filho do deus Brahma.

A legislação de Manu pressupõe a divisão da sociedade em castas (brâmanes, ksatriya, vaisya e sudras). Como não poderia deixar de ser, esta divisão em castas, transplantada para a legislação penal, possuiu o condão de estabelecer distinções entre as $\operatorname{condutas}^{19}$. Assim, uma conduta delituosa praticada por um brâmane, membro da casta mais alta, em detrimento de um sudra poderia ser desconsiderada, ao passo que o crime praticado pelo membro de uma casta inferior em desfavor de um integrante de uma casta superior seria encarado como ofensa gravíssima, merecedora de uma reprimenda penal efetiva e, no mais das vezes, cruel. Mais que isto, um brâmane que soubesse o texto sagrado poderia cometer, impunemente, qualquer fato ${ }^{20}$.

Percebe-se, neste particular, que a legislação penal, impregnada, como sói acontecer, de forte caráter religioso, fora utilizada como instrumento de preservação da estrutura social, estratificada em castas. Atentados contra a rígida hierarquia das castas eram reprimidos com o rigor de uma penalidade cruel.

\footnotetext{
${ }^{18}$ Idem. p.33.

${ }^{19}$ Ao discorrer sobre o sistema de castas e a sua influência na legislação penal, afirma A. L. Machado Neto que, in verbis: "Desse sistema social geralmente decorrente de conquista militar ou algo análogo, envolvendo povos, no comum, de raças diversas e fundado em bases tradicionais, via de regra de caráter religioso ( $v . g$. as castas hindus, o padrão mais típico), resulta, no âmbito normativo do direito, que a lei reconheça as diversidades de condição social estabelecendo diferentes sanções para um mesmo delito, caso seja ele cometido por um membro de uma casta superior ou por um outro de menor status social" (MACHADO NETO, A. L. Sociologia jurídica. 6. ed. São Paulo: Saraiva, 1987, p.261).

${ }^{20}$ ZAFFARONI, Eugênio Raul; PIERANGELI, José Henrique. Ob. cit. p.177.
} 
A punição, para a legislação de Manu, possuía uma função de purificação para o condenado. Assim, uma vez cumprida a pena que lhe fora aplicada, o condenado estaria purificado, tal como os homens que praticavam apenas boas ações. Como características desta legislação, podem ser mencionadas a diferenciação entre dolo e culpa e entre furto e roubo.

Merece destaque, ainda, a questão da sanção penal na América antiga, período histórico que antecede a chegada dos europeus. Civilizações extremamente desenvolvidas, em inúmeros aspectos, os maias e os incas também desenvolveram seu sistema penal com uma acentuada severidade. Os astecas utilizavam-se da pena de morte, além de penas como o desterro, a escravidão, o confisco, a destituição do emprego, e, até mesmo, a prisão ${ }^{21}$. Por seu turno, o incas, cujo caráter sacral das sanções era mais presente do que na civilização asteca, também se valiam destas penas, mas a sua aplicação sempre foi entendida como desagravo aos deuses ${ }^{22}$, tal como na época das vinganças divinas ${ }^{23}$.

\section{Direito Penal: primeiras noções de proporcionalidade}

Como visto, os primeiros tempos do Direito Penal ${ }^{24}$ foram marcados pela desproporção entre o ato praticado e a sanção respectiva. A primeira concepção de obediência à proporcionalidade entre delitos e penas surge com o Código de Hamurabi que, ao institucionalizar a lei do talião (imortalizada na máxima "olho por olho, dente por dente"), preconizou um limite objetivo à reprimenda penal.

\footnotetext{
${ }^{21}$ CORREA JUNIOR, Alceu; SHECAIRA, Sérgio Salomão. Teoria da pena: finalidades, direito positivo, jurisprudência e outros estudos de ciência criminal. São Paulo: RT, 2002, p.28.

${ }^{22}$ CORREA JUNIOR, Alceu; SHECAIRA, Sérgio Salomão. Ob. cit., p.28.

${ }^{23}$ Ainda no que tange à questão das penas nestas civilizações indígenas, convém esclarecer que não era raro a utilização da tortura. Todavia, salienta Pierre Clastres que a tortura nem sempre possuía caráter de sanção penal, sendo utilizada, por vezes, como rito de passagem para a idade adulta. O objetivo do ritual é infligir dor ao membro da tribo, para, assim, ensinar-lhe algo, sobretudo a idéia de igualdade. Sobre o tema, afirma Clastres: “Os primeiros cronistas diziam, no século XVI, que os índios brasileiros eram pessoas sem fé, sem rei, sem lei. É certo que essas tribos ignoravam a dura lei separada, aquela que, numa sociedade dividida, impõe o poder de alguns sobre todos os demais. Tal lei, lei de rei, lei de Estado, os Mandan, os Guaykuru, os Guayaki e os Abipones a ignoram. A lei que eles aprendem a conhecer na dor é a lei da sociedade primitiva, que diz a cada um: Tu não é menos importante nem mais importante do que ninguém. A lei, inscrita sobre os corpos afirma a recusa da sociedade primitiva em correr o risco da divisão, o risco de um poder separado dela mesma, de um poder que lhe escaparia. A lei primitiva, cruelmente ensinada, é uma proibição à desigualdade de que todos se lembrarão. Substância inerente ao grupo, a lei primitiva faz-se substância do indivíduo, vontade pessoal de cumprir a lei." (CLASTRES, Pierre. A sociedade contra o Estado: pesquisas de antropologia política. Tradução: Theo Santiago. São Paulo: Cosac Naify, 2003, p.203).

${ }^{24}$ Para alguns autores, sequer há que se falar em Direito Penal quando da vigência das vinganças divina e privada. Neste sentido, BITENCOURT, César Roberto. Ob. cit., p.38.
} 
Assevera Francesco Carnelluti ${ }^{25}$ que, nesta época, a idéia de proporcionalidade estava assentada em uma concepção qualitativa, manifestada na semelhança entre a pena e o delito. A pretensão era submeter o réu a um mal semelhante àquele praticado, ou seja, da mesma qualidade do mal praticado contra a vítima. Posteriormente, com a incriminação de novas condutas e a constatação da impossibilidade de fazer valer esta lógica, a proporcionalidade deixa de ser qualitativa e passa a ser quantitativa, isto é, a pena deve servir a que o réu sofra tanto quanto a vítima, e não como a vítima ${ }^{26}$.

Hamurabi reinou na Babilônia em meados do século XXIII a.C. e editou o seu Código, que continha disposições na seara do Direito Civil, bem como a definição de condutas delituosas com as suas respectivas sanções. Tendo sido o fundador do Império Babilônico, Hamurabi foi o primeiro a alterar o Direito Penal, até então dotado de conteúdo privado, institucionalizando os delitos e as sanções respectivas.

O caráter teocrático do Código é flagrante, na medida em que, em seu preâmbulo, assevera que o Rei Hamurabi fora convocado pelos deuses (Anu e Bel) para sedimentar a justiça entre os homens, destruir os maus e criminosos, evitar que os fortes ferissem os fracos, trazer esclarecimento à Terra e, por fim, assegurar o bem-estar da humanidade.

O Código de Hamurabi era composto por 282 artigos, e possuía disposições extremamente curiosas, tais como as previstas nos artigos 209 e 210. De acordo com o primeiro, se um homem agredisse uma mulher livre (já que a legislação em comento estabelecia a distinção entre livres e escravos) e esta perdesse o filho que esperava, o agressor deveria pagar-lhe (10 shekels) pela perda. Porém, se a própria agredida morresse, a filha do agressor seria condenada à morte. Para logo se vê que a referida legislação não primava pela observância do princípio da intranscendência ou pessoalidade da pena, tampouco pela idéia de culpabilidade, como juízo de reprovação pessoal.

Muitas outras penas eram utilizadas por esta legislação, como, por exemplo, as múltiplas modalidades de pena capital (na hipótese de alguém ser flagrado durante um arrombamento, além de morto seria emparedado; se alguém cometesse um delito de furto durante um incêndio, deveria ser atirado às chamas; a mulher que cometesse adultério seria atirada ao rio com as mãos $\operatorname{atadas}^{27}$ ).

\footnotetext{
${ }^{25}$ CARNELUTTI, Francesco. Liçães sobre o processo penal, Tradução: Francisco José Galvão Bruno. Campinas: Bookseller, 2004, p.104. Tomo I.

${ }^{26}$ Idem, p. 104.

${ }^{27}$ ZAFFARONI, Eugênio Raul; PIERANGELI, José Henrique. Ob. cit. p.178.
} 
Outros crimes e penas podem ser mencionados: a expulsão da comunidade para o crime de incesto; a amputação das mãos na hipótese de um filho que agredisse o pai (art. 195) ou das orelhas, para o escravo que batesse em um homem livre (art. 205), ou do seio para a ama que aleitasse outra criança sem permissão, dando ensejo à morte da criança que deveria aleitar (art. 194).

Como dito, o Código de Hamurabi consagrou a existência da lei do talião, insculpida na célebre expressão "olho por olho, dente por dente". Diz-se que o Código de Hamurabi foi a primeira legislação a consagrar o princípio da proporcionalidade, na medida em que a idéia de "olho por olho, dente por dente" materializa uma proporção entre o delito praticado e a pena correlata.

Muito embora a idéia de "olho por olho, dente por dente" possa trazer consigo uma carga de crueldade e desumanidade na aplicação das sanções, o fato é que, ao preconizar que a reprimenda deveria ser idêntica à lesão perpetrada, a lei do talião institucionalizou a idéia de proporcionalidade entre o delito e a pena, constituindo progresso em relação ao quadro anterior ${ }^{28}$.

Naturalmente, esta idéia de proporcionalidade é primitiva e limitada para os padrões de desenvolvimento do conhecimento científico em matéria penal da atualidade. Como toda notícia histórica, a importância do advento da proporcionalidade com o Código de Hamurabi deve ser inserida em seu contexto histórico ${ }^{29}$. Com isto, salutar deixar claro que não é esta concepção tacanha e rudimentar de proporcionalidade entre delito praticado e pena cominada que há de servir de baliza para legitimação do poder de punir nos Estados modernos.

Demais disso, relevante deixar consignado que a lei do talião fora acolhida não apenas pelo Código de Hamurabi, mas por inúmeras outras legislações da antiguidade, como a Lei das XII Tábuas dos romanos e o Pentateuco hebreu ${ }^{30}$, além do, já mencionado, Código de Manu.

\footnotetext{
28 "O talião, que atualmente nos povos civilizados é símbolo de ferocidade bárbara, foi na humanidade primitiva um grande progresso moral e jurídico, justamente porque impôs um limite, uma medida à reação pela vindita defensiva (olho por olho, dente por dente)". (FERRI, Enrico. Princípios de direito criminal: o criminoso e o crime. Tradução: Luis Lemos D’Oliveira. Campinas: Russell Editores, 2003, p.22).

${ }^{29}$ Ao se referir aos estreitos limites desta idéia de proporcionalidade, na lei de talião, assevera Jeremy Bentham que, in verbis: "A lei deve medir a pena pelas circunstâncias agravantes, ou que podem diminuir o crime; o Talião destrói toda a medida. Só os Povos vingativos devem gostar desta pena." (BENTHAM, Jeremy. Teoria das penas legais. São Paulo: Edijur, 2002, p.50).

${ }^{30}$ Em que pese o cristianismo possuir matriz hebraica, cumpre ressaltar que a lei do talião foi defenestrada por esta corrente de pensamento, na medida em que, para Jesus-Cristo, nas palavras do apóstolo Mateus, in verbis: "Ouviste que foi dito: olho por olho, e dente por dente. Eu, porém, vos digo que não resistais ao mal; mas se
} 
Como dito, a legislação penal hebraica também se assentou sobre a idéia de talião. O divisor de águas na legislação da civilização hebraica, sem dúvidas é o advento dos Dez Mandamentos, enviados por Javé a Moisés, que deram origem ao chamado Direito Penal mosaico.

A civilização hebraica, em sua maioria, era constituída por pastores com baixo nível de instrução e dotados de uma forte influência religiosa. Moisés ingressa em uma luta para consolidar o monoteísmo, expurgando as práticas, adorações e celebrações em homenagem a divindades. Demais disto, para a concepção em vigor à época, seria necessário impingir um senso de moral bastante rígido, para que não vicejassem as práticas consideradas viciosas e imorais.

À vista disto, além de seu marcante traço religioso, o Direito Penal mosaico caracteriza-se pela imposição de condutas morais rígidas, com respectivas sanções inflexíveis para o caso de descumprimento. Com o passar do tempo, esta legislação foi sofrendo pequenas alterações, mas sempre assentada na idéia de delegação divina.

Desta forma, sustentava-se a tese de que, a par da lei escrita, plasmada nos Dez Mandamentos, Deus haveria conferido a Moisés uma lei oral, que teria se perdido, e cujas conseqüências deveriam ser deduzidas a partir da lei escrita. Os responsáveis por estes juízos de dedução eram os doutores da lei, em Israel, os Rabis, ligados ao sacerdócio. No Direito Penal hebraico eram aplicadas: a pena capital (para delitos como o adultério e o incesto), a excomunhão, a privação de sepultura, a pena pecuniária, entre outras. .

Outra notícia histórica que se tem da proporcionalidade entre delitos e penas, insculpida em um documento, refere-se à Magna Carta, de 1215, cujo teor previa que condes e barões haveriam de ser castigados apenas pelos seus iguais, e na proporção da gravidade das ofensas praticadas ${ }^{31}$. A despeito do seu caráter elitista, a Magna Carta representa um importantíssimo documento, no sentido da consolidação de direitos ${ }^{32}$ - é a partir dela, para muitos juristas ${ }^{33}$, que podem ser extraídos os fundamentos da ordem jurídica democrática da Inglaterra -, dentre os quais se inclui, como visto, a proporcionalidade da sanção penal.

qualquer te bater na face direita, oferece-lhe também a outra; e ao que quiser pleitear contigo, e tirar-te o vestido, larga-lhe também a capa" (Mt, 05: 38-40).

${ }^{31}$ Tradução livre de: "Earls and barons shall be fined only by their equals, and in proportion to the gravity of their offence" (item 21).

32 "Se é certo que a Magna Charta efetivamente deixou a esmagadora maioria da população sem acesso aos direitos nela previstos, não menos é que serviu como um dos marcos para a consolidação de importantes direitos e garantias fundamentais, como o caso do habeas corpus e do direito de propriedade" (SILVA NETO, Manoel Jorge e. Curso de direito constitucional. 3. ed. Rio de Janeiro: Lumen Juris, 2008, p. 42).

${ }^{33}$ SILVA, José Afonso da. Curso de direito constitucional positivo. 15. ed. São Paulo: Malheiros, 1998, p.156. 


\section{Direito Penal laicizado}

\subsection{Direito Penal na Grécia}

Muito embora também possuam como característica o surgimento da lei como parte da religião ${ }^{34}$, as civilizações grega e romana constituem um marco no processo de laicização da intervenção penal. Como visto, até então a legislação penal era dotada de uma forte influência teocrática e sacerdotal. Em síntese, a legitimação do poder de punir era encontrada na divindade. Como regra geral, a própria divindade, perfeita, impassível de cometer equívocos, delegava o sagrado poder de punir a determinado grupo de pessoas - os sacerdotes. Aí residia o fundamento da legitimação da aplicação de penas aos membros do grupo.

A Grécia não conhece este caráter teocrático da legislação penal. Como cediço, a civilização grega também possui uma forte influência religiosa. Sendo politeístas, os membros das cidades-estado gregas prestavam cultos às mais variadas divindades, tendo Zeus como um deus de hierarquia superior, sendo identificado como o deus dos deuses. A religião grega legou o que, na atualidade, convencionou-se denominar mitologia grega.

Esta presença da religião politeísta, porém, se por um lado foi muito marcante na vida social dos gregos, por outro não exerceu maior influência sobre o poder de punir. Em suma, os gregos não julgavam para desagravar os deuses, nem tampouco consideravam que este poder de punir encontrava sua legitimação na delegação divina.

Certamente esta postura da civilização grega decorreu do significativo avanço, por ela experimentado, no que tange à política. Com efeito, a civilização grega foi dividida em pólis, cidades-estados, com considerável grau de autonomia, sendo que algumas pólis possuíam uma estrutura política bastante progressista, para os padrões então vigentes. Sem dúvida, o maior exemplo disto é a cidade-estado de Atenas. Todavia, em que pese haver uma notável distinção entre as formas de organização de cidades-estados como Atenas e Esparta (cidade militarizada), em um ponto havia expressiva coincidência: em ambas, não há que se falar em reflexo da religião sobre a legislação penal.

Naturalmente, esta laicização do Direito Penal na Grécia decorreu de um processo histórico, na medida em que, em seus primórdios, também existia a referência à

\footnotetext{
34 "Entre gregos e romanos, assim como entre hindus, desde o princípio a lei surgiu naturalmente como parte da religião. Os antigos códigos da cidade reuniam um conjunto de ritos, de prescrições litúrgicas, de orações e, ao mesmo tempo, de disposições legislativas." (COULANGES, Fustel. A cidade antiga. 2.ed. Tradução: Jean Melville. São Paulo: Martin Claret, 2001, p.206).
} 
religião. Desta forma, não se pode olvidar que quando do advento das leis draconianas ainda existiam resquícios do direito religioso dos eupátridas ${ }^{35}$.

Dracon fora convocado para redigir a primeira lei escrita de Atenas, tendo em vista a iminência de um conflito entre as classes sociais de então. As leis draconianas eram extremamente rígidas, mas, durante algum tempo, gozaram de prestígio entre os gregos, justamente por possuírem o mérito de extirpar as surpresas na condenação. Em outras palavras, com a existência da legislação draconiana, os gregos tinham prévia ciência dos fatos taxados como criminosos.

Porém, a legislação draconiana mantinha privilégios concedidos às classes dominantes, além de prever sanções excessivamente severas para condutas de menor importância. Com a crescente insatisfação das classes excluídas das benesses concedidas aos eupátridas, Sólon elaborou uma nova legislação, consagrando a igualdade perante a lei e a extinção da escravidão por dívidas ${ }^{36}$.

\subsection{Direito Penal em Roma}

Despiciendo incorrer em maiores digressões acerca da importância do Direito em Roma e sua influência nas legislações ocidentais da atualidade, mormente aquelas pautadas no paradigma da civil law. A despeito desta relevância não se pode perder de vista a célebre expressão de Carrara, para quem os romanos foram gigantes em Direito Civil e pigmeus em Direito Penal.

Esta afirmação, malgrado a envergadura intelectual de seu autor, há de ser aferida com uma certa dose de temperamento. Isto porque, se por um lado não se pode negar que o desenvolvimento do civilismo fora de fundamental importância para os avanços das legislações nesta seara, não se pode afirmar, em absoluto, que os romanos não lograram êxito em contribuir com o avanço do Direito Penal ${ }^{37}$.

Como ocorreu nas demais civilizações, em seus primórdios, os romanos se pautaram por uma legislação penal de teor religioso ${ }^{38}$. Nesta fase, destaca-se a figura do pater famílias, que possuía uma gama de poderes quase ilimitados sobre os membros do seu grupo

\footnotetext{
${ }^{35}$ FÜHRER, Maximiliano Roberto Ernesto. Ob. cit. p.34.

${ }^{36}$ FÜHRER, Maximiliano Roberto Ernesto. Ob. cit., p.35-36.

37 "É inegável, então, que, apesar de não haverem os romanos atingido, no direito penal, as alturas a que se elevaram no civil, se avantajaram a outros povos." (MAGALHÃES NORONHA, E. Direito penal. Vol I. Atualizado por Adalberto J.Q.T. de Camargo Aranha. 33 ed. São Paulo: Saraiva, 1998, p.22).

${ }^{38}$ ZAFFARONI, Eugênio Raul; PIERANGELI, José Henrique. Ob. cit. p.182.
} 
familiar, inclusive o direito de vida e morte ${ }^{39}$. Até este momento histórico, este poder do chefe da família não poderia ser alterado por qualquer autoridade, suas decisões eram inapeláveis e não havia intervenção do poder público constituído sobre os fatos que lhe competiam.

A edição da Lei das XII Tábuas constitui marco na legislação penal romana. Neste momento histórico, Roma assistia a eclosão de uma revolta social, resultante da luta entre a plebe e o patriciado. Uma das principais reivindicações dos integrantes da plebe era a edição de uma legislação penal, para que, desta forma, houvesse um limite ao poder dos magistrados, membros do patriciado, que se valiam do arbítrio punitivo contra a plebe ${ }^{40}$.

O tribuno da plebe, Terentílio Arsa, propôs a criação de um grupo destinado à elaboração de um código destinado à plebe ${ }^{41}$. Temendo a separação da plebe, em relação a si, o patriciado decidiu pela criação da magistratura constituída de dez membros, cujo objetivo seria a elaboração de um código, não apenas para os plebeus, mas para todos os romanos. Este grupo adotou como paradigma a legislação ateniense, de Sólon ${ }^{42}$. Assim surge a Lei das XII Tábuas, entre os anos 451 a.C. e 450 a.C., que, como já referido, também acolheu a lei do talião $^{43}$.

O Direito Penal romano consagrou a distinção entre os ilícitos públicos (crimina) e os privados (delicta), sendo que estes últimos eram considerados ofensa ao próprio indivíduo, razão pela qual a persecução não ficava confiada ao Estado, mas sim ao particular. Após, na época do Império, surgiu uma terceira espécie de infração, chamada de extraordinária (crime majestatis ${ }^{44}$ ), e consistia nas condutas que ofendessem o poder público, sobretudo a autoridade do Imperador.

O Direito Penal Público romano tem início com a edição da Lex Valeria, no ano de 509 a.C., cujo mérito fora submeter à ratificação popular as decisões judiciais que

\footnotetext{
${ }^{39}$ PRADO, Luis Régis. Curso de direito penal brasileiro. Vol. I: parte geral. 5. ed. São Paulo: Editora Revista dos Tribunais, 2005, p.68-69.

${ }^{40}$ MOREIRA ALVES, José Carlos. Direito romano. Vol. I. 10.ed. Rio de Janeiro: Forense. 1998, p.24.

${ }^{41}$ Idem, p.24.

${ }^{42}$ MOREIRA ALVES, José Carlos. Ob. cit., p.24.

${ }^{43}$ Ao discorrer sobre a lei do talião, Montesquieu chama a atenção para a peculiaridade de sua adoção na legislação em Roma, in verbis: "Os Estados Despóticos, que apreciam leis simples, usam frequentemente a lei de talião; os Estados moderados adotam-na algumas vezes. Entretanto, existe uma diferença: os primeiros a exercem rigorosamente, e os segundos a usam moderadamente. (...). A lei das Doze Tábuas admitia duas modalidades: apenas condenava à pena de talião quando não podia apaziguar o queixoso; era permitido, depois da condenação, pagar as perdas e danos, convertendo a pena corporal em pecuniária" (MONTESQUIEU, Charles de Secondat. O espírito das leis. Tradução: Jean Melville. São Paulo: Martin Claret, 2002, p.105).

44 "O conceito de crime contra o Estado (crime majestatis) chegou a limites tão absurdos no Império, que se considerava como tal desnudar-se diante de uma estátua do imperador, vender sua estátua consagrada, levar uma medalha ou moeda com sua imagem a um prostíbulo, fazer vestidos ou tecidos púrpura (consideradas cor imperial), ter relações sexuais com princesa imperial, duvidas do acerto do imperador na escolha de funcionários e, em geral, qualquer classe de crítica" (ZAFFARONI, Eugênio Raul; PIERANGELI, José Henrique. Ob. cit. p.183).
} 
cominassem a pena de morte prolatada por magistrados em desfavor daqueles que possuíssem cidadania romana. Desta forma, os cidadãos romanos, em casos que tais, poderiam recorrer à provocatio ad populum ${ }^{45}$.

Como característica marcante do Direito Penal romano encontra-se o desenvolvimento de institutos como o da culpabilidade e da imputabilidade. Havia, ainda, a possibilidade de reconhecimento de excludentes de ilicitude, como a legítima defesa e o estado de necessidade. Em contrapartida, o Direito Penal romano não preconizou a previsão expressa do princípio da legalidade, tampouco proibiu ou restringiu a utilização da analogia em matéria penal. Demais disso, realizou um desenvolvimento parcial do instituto da tentativa.

Deste estudo da manifestação do Direito Criminal em Roma e na Grécia, o que se percebe é que, a despeito do significativo avanço da intervenção penal em relação às demais civilizações, ainda se consagrava a afronta à idéia de proporcionalidade entre o desvio de conduta social e a sanção pertinente. Neste sentido, convém esclarecer que, no que toca à proporcionalidade penal, o maior avanço na Antiguidade deve-se, efetivamente, ao Código de Hamurabi, na medida em que, as demais legislações, grosso modo, adstringiram-se a, no que concerne à proporcionalidade, reproduzir os dispositivos da Lei de Talião.

\section{Direito Penal medieval}

Durante a Idade Média, período histórico denominado, por muitos, como idade das trevas, a repressão penal ainda estava longe de se pautar por critérios de humanização na aplicação da pena. Com efeito, o excessivo rigor na aplicação das sanções é uma das características marcantes do período. A utilização irrestrita da tortura como meio de obtenção de provas para incriminação é outro dado presente na persecução criminal da época.

Outra informação de relevo reside no fato de que o Direito Penal medieval não primou pela observância do princípio da legalidade. Em consequência, ao julgador, encarregado da aplicação da pena, facultava-se não apenas a cominação de sanções, como, também, a incriminação de condutas não previstas em lei, escrita e prévia ${ }^{46}$.

Sabe-se que uma das peculiaridades da Idade Média, nas civilizações ocidentais, é a hegemonia política e econômica da Igreja Católica Apostólica Romana, que, além disto, monopolizava a divulgação do conhecimento, sendo certo que, muitas obras de

\footnotetext{
${ }^{45}$ PRADO, Luis Régis. Ob. cit. p.70.

${ }^{46}$ BRANDÃO, Cláudio. Ob. cit., p.26.
} 
fundamental importância para o pensamento filosófico encontravam-se nos mosteiros medievais. À vista deste contexto, a influência religiosa no Direito fora marcante neste período.

Relata Cláudio Brandão ${ }^{47}$ que o pensamento da época respaldava a existência de três tipos de leis, a saber: (i) a lei eterna (lex aeterna), que seria a vontade de Deus, a reger o universo; (ii) a lei natural (lex naturalis), que seria o reflexo da vontade de Deus, isto é, da lei eterna, na mente humana; (iii) a lei humana (lex humanae) que seria a lei temporal do Estado. Assentada na, já mencionada, forte concepção religiosa, eventual conflito entre a lei natural e a lei humana deveria redundar na prevalência da primeira ${ }^{48}$, na medida em que o poder divino possui primazia, eis que superior ao poder humano.

Demais disto, o Direito Penal canônico estabelecia a distinção entre delitos eclesiásticos, seculares e mistos. Os primeiros, para os quais possuía competência absoluta para o julgamento, referiam-se às práticas heréticas. Muito embora haja entendimento no sentido de que o Direito Penal canônico, ao estabelecer estas distinções, apartou por completo o delito do pecado, prevalece a idéia de que não houve esta distinção, mantendo-se a confusão entre infrações religiosas e infrações criminais ${ }^{49}$.

Consectário desta hegemonia da religião católica sobre a vida social foi o advento da Inquisição, mediante a restauração dos Tribunais do Santo Ofício. A Inquisição objetivou restaurar a força da Igreja, reprimindo as condutas consideradas heresias, sobretudo aquelas relacionadas ao que se considerava bruxaria.

Há um certo consenso em relação à influência do movimento de Reforma, levada a cabo por Martinho Lutero, como uma das razões de instauração da Inquisição. Como cediço, este movimento (implantação dos Tribunais do Santo Ofício) representou uma atroz repressão de matriz religiosa, sendo célebres as figuras de alguns dos mais implacáveis inquisidores, como Torquemada.

No que importa ao Direito Penal, relevante consignar que a Inquisição valia-se de um poder de punir, justificado por questões religiosas, cujo processo caracterizou o que se convencionou denominar sistema inquisitivo. São características do sistema inquisitivo: a coincidência nos papéis de acusação e julgamento, realizados pela mesma pessoa, a ausência de publicidade nos julgamentos, a inexistência do amplo direito à defesa, a legitimação de provas como a tortura, em que competia à parte provar a sua inocência, e não à acusação

\footnotetext{
${ }^{47}$ Idem, p.30.

${ }^{48}$ Idem, ibidem, p.30.

${ }^{49} \mathrm{Na}$ defesa desta tese, cf. ZAFFARONI, Eugênio Raul; PIERANGELI, José Henrique. Ob. cit. p.185.
} 
provar a responsabilidade do réu. Por conta disto, não havia que se falar em presunção de inocência. Estas características, posteriormente, conduzem à adoção do sistema processual inquisitivo por regimes políticos autoritários ${ }^{50}$.

Documento que orientou a prática inquisitiva dos Tribunais do Santo Ofício foi o Manual dos Inquisidores, escrito em 1376 pelo catalão Nicolau Eymerich, revisado e ampliado em 1578 por Francisco de la Pena ${ }^{51}$.

A Inquisição não se preocupava com o crime, isto é, com a afronta com as leis terrenas, mas sim com as heresias, isto é, a suposta afronta às leis divinas. A lógica que orientava esta postura residia no fato de que o crime não comprometia a marcha para a vida eterna, porquanto o arrependido poderia valer-se do perdão de Deus. Em contrapartida, a heresia obsta a marcha para a eternidade, constituindo um perigo muito maior do que o crime, e por isto merecia um rigor maior na reprimenda ${ }^{52}$.

Outro ponto de destaque do sistema inquisitivo refere-se à pretensão de se buscar a verdade real. Este fundamento legitimou a utilização de métodos espúrios na busca desta famigerada verdade, em descompasso com os direitos do acusado, relegados a plano secundário. É também a pretensa obtenção da verdade real que serviu de supedâneo à legitimação da junção das funções de acusar e de julgar, malgrado o flagrante comprometimento da imparcialidade do julgador ${ }^{53}$. A ampla aptidão para produção de provas por parte do magistrado, outro elemento constitutivo do sistema inquisitivo também fora legitimado por esta incessante busca pela verdade real ou material.

Característica marcante do Direito Penal durante o medievo foi a presença dos juízos de Deus, isto é, os ordálios, utilizados, por exemplo, no direito germânico, quando não fosse possível realizar nem as provas por testemunho nem as provas por juramento, ou, ainda, quando o demandado deixasse de comparecer, injustificadamente, ao Tribunal ${ }^{54}$.

\footnotetext{
${ }^{50}$ PRADO, Geraldo. Sistema acusatório: a conformidade constitucional das leis processuais penais. 4 . ed., Rio de Janeiro: Lumen Juris, 2006, p,141.

${ }^{51}$ LOPES Jr., Aury. Introdução crítica ao processo penal. 4 ed. Rio de Janeiro: Lumen Juris. 2006, p.169.

${ }^{52}$ LOPES Jr., Aury. Ob. cit. p.169.

53 "Sólo un juez dotado de uma capacidad sobrehumana podría substraerse em su actividad decisoria a los influjos subjetivos de su propia actividad agresiva e investigatoria" (SCHMIDT, Eberhard. Los fundamentos teóricos e constitucionales del derecho procesal penal. Traduccion castellana de José Manuel Nuñez, Buenos Aires: Lerner, 2006, p.193).

${ }^{54}$ KEMMERICH, Clóvis Juarez. O direito processual da Idade Média. Porto Alegre: Sérgio Antônio Fabris Editor, 2006, p.63. Referido autor fornece alguns exemplos de utilização dos ordálios, in verbis: "Julgamento da cruz: 'no iudicium crucis (= julgamento da cruz), bastante difundido na época carolíngia, as duas partes deviam ficar de braços estendidos; o primeiro que deixasse cair os braços perdia a questão.' Prova do cadáver: a 'prova do cadáver (al. Bahrprobe) consistia para o acusado em tocar o cadáver sem o fazer sangrar; subsistiu na Suíça e na Alemanha até o século XVI'. Julgamento pelo ferro incandescente: o interessado devia carregar um pedaço de ferro incandescente por cerca dos pés. Sua mão era então enfaixada e recebia um selo. No terceiro dia as faixas eram retiradas: se estivessem limpas, ou o ferimento apresentasse um indício de cura, significava que o veredicto
} 
As mesmas considerações tecidas quando da apreciação do Direito Penal em Roma e na Grécia podem ser utilizadas aqui. Com efeito, o Direito Penal aplicado no medievo foi marcado por uma reprimenda penal excessiva, sob o ponto de vista dos suplícios impingidos, em descompasso à idéia de proporcionalidade entre delito e sanção.

\section{Período Humanitário: o Direito Penal liberal}

\subsection{Ideário iluminista e humanização do Direito Penal: a contenção do poder punitivo}

A previsão de relativa proporcionalidade entre os delitos praticados e as sanções penais a serem impostas não eliminava a crueldade das penas. Com efeito, até o século XVIII os países da Europa conviviam com execuções bárbaras, transformadas em tenebrosos espetáculos públicos ${ }^{55}$. Se é certo que a proporcionalidade já conduzia o poder público a repudiar tais excessos para os delitos de pouca monta, isto é, de baixa lesividade, é certo também que, quando da prática de crimes considerados mais graves, a prática destas atrocidades constituía uma constante.

Até o advento da revolução burguesa, na França, a Europa vivia sob a égide do Antigo Regime que, na política, caracterizou-se pela primazia do absolutismo monárquico. A célebre expressão do Rei Luís XIV (L'État c'est moi), conhecido como Rei-sol, é assaz paradigmática. Sem embargo, se a figura do Estado e a do monarca coincidem, como afirmara Luis XIV, a sua vontade é a vontade do Estado, sem necessidade de obediência a regras previamente estabelecidas.

Este tipo de concentração de poder conduziu a uma série de arbitrariedades perpetradas pelos representantes do Estado, sobretudo os membros da magistratura, cujas decisões, no mais das vezes, assentavam-se em parâmetros subjetivos. Mais que isto, por vezes este subjetivismo na apreciação da conduta posta em juízo constituía afronta à idéia de

\footnotetext{
de Deus era favorável àquele submetido à prova. Julgamento pela água fervente: o 'judicium aquae colidae é a versão úmida dessa delicada atenção: deve-se mergulhar a mão na água fervente.' Logo após, seguia-se o mesmo procedimento do julgamento pelo ferro incandescente. Julgamento pela água fria: a parte à qual coubesse a prova era amarrada e jogada em um rio ou tina de água fria. '[S]e ele afunda, tem razão, se bóia, está errado (...). A água divina rejeitou o seu recurso. Em outras variantes, o fato de não afundar significava exatamente o contrário, ou seja, que aquele submetido ao teste era inocente. Julgamento pelo pão: a parte a quem coubesse a prova deveria comer um pedaço de pão ou de queijo pesando cerca de uma onça. Se não engasgasse, nem ficasse com migalhas na garganta, o veredicto de Deus era tido como favorável." (KEMMERICH, Clóvis Juarez. Ob. cit. p.64-65).

${ }_{55}$ Para uma breve noção do que aqui se afirma, cf. FOUCAULT, Michel. Vigiar e punir: nascimento da prisão. Tradução: Raquel Ramalhete. 32. ed. Petrópolis: Vozes, 1987, p.09-10.
} 
Estado laico, na medida em que os magistrados, com fundamento em suas considerações pessoais acerca da identificação entre delito e pecado, decidiam quando, como e porque $\operatorname{punir}^{56}$.

Para logo se vê que o fundamento de legitimação do poder de punir, quando da vigência do Estado absolutista, centra-se na própria autoridade do monarca. Esta a razão pela qual os atos considerados mais graves, neste período histórico, dizem respeito, justamente, a condutas contrárias ao poder real, ou à pessoa do Rei. A estas estavam reservadas as sanções mais cruéis, cujo objetivo, para além de punir, era exemplificar. Punia-se com rigor excessivo para que os demais súditos não ousassem seguir o exemplo ${ }^{57}$.

O arbítrio até então reinante na esfera política começa a ceder espaço com o advento das idéias sufragadas pelos pensadores iluministas. Na seara das ciências criminais, as teses sustentadas pelos pensadores iluministas caminharam no sentido da humanização da intervenção penal. De início, imperioso destacar que, com fundamento no direito natural, os iluministas defendiam que toda pessoa possuiria direitos inalienáveis, imanentes a sua própria natureza $^{58}$, razão pela qual a intervenção penal há de obedecer a critérios de racionalidade.

Sob outra perspectiva, no campo estritamente político, os pensadores iluministas insurgiam-se contra o poder absoluto do monarca. Ora, sendo o Direito Penal o meio pelo qual o poder público exerce a violência, legitimamente monopolizada pelo Estado, a limitação do poder do monarca relaciona-se, intimamente, com os freios à persecução criminal.

\footnotetext{
${ }^{56}$ ANITUA, Gabriel Ignácio. Histórias dos pensamentos criminológicos. Tradução: Sergio Lamarão. Rio de Janeiro: Revan: Instituto Carioca de Criminologia, 2008, p.109.

${ }^{57}$ Ao discorrer, de forma minuciosa sobre o rigor destes suplícios e a simbologia da sua aplicação, Gabriel Ignácio Anitua descreve dois casos paradigmáticos, cuja riqueza de detalhes merece transcrição. A primeira execução descrita refere-se à pena aplicada a Juan de Camañas, em 07 de dezembro de 1492, em Barcelona, acusado de haver atentado contra a vida do Rei Fernando, o Católico. Relata Anitua que, in verbis: "Ele foi posto em uma carroça e arrastado por toda a cidade; primeiramente teve cortada a mão que atacou o rei e depois, com tenazes de ferro ardendo, lhe tiraram um mamilo, e depois the arrancaram um olho, e depois the cortaram a outra mão, e logo lhe retiraram o outro olho e em seguida o outro mamilo, e depois as narinas, e todo o seu corpo foi sendo destroçado pelos ferreiros com tenazes ardentes e os pés foram cortados e depois que todos os membros foram cortados, lhe arrancaram o coração pelo peito e o arrastaram para fora da cidade, o apedrejaram e o queimaram em fogo e lançaram as cinzas ao vento" (Ob. cit. p.110). O outro caso relatado por Anitua diz respeito ao homicídio perpetrado por François Ravaillac contra Henrique IV, no início do século XVII. Ao transcrever trecho da sentença que condenou Ravaillac, assinala o autor que constava, in verbis: "'Declarará que sente remorso por isso e pede perdão ao rei e à justiça. Depois será levado à praça da Grève, onde será erguido o cadafalso, sobre o qual serão arrancados dele, com tenazes, pedaço das carnes dos mamilos, dos braços, das coxas e das nádegas. Sua mão direita, que empunhou a arma assassina, será queimada no fogo de enxofre. E nas partes de seu corpo de onde foram arrancados pedaços de carne com as tenazes será lançado chumbo derretido, azeite fervendo, água de ebulição e enxofre ardendo. Finalmente, seu corpo será despedaçado por meio de quatro cavalos atados a seus membros, os quais, uma vez desprendidos de seu corpo, serão queimados e suas cinzas dispersas ao vento"' (Ob. cit. p.111).

${ }^{58}$ Neste sentido, paradigmática a frase de Jean-Jacques Rousseau: "O homem nasceu livre, e em todo canto se encontra sob ferros". Tradução livre de: "L'homme est né libre, et partout il est dans les fers". (ROUSSEAU, Jean-Jacques. Du contrat social. Paris: Éditions Sociales, 1955, p.05).
} 
Nesta senda, sobressai-se em importância, além da obra de célebres autores, como Rousseau e Montesquieu ${ }^{59}$, o opúsculo "Dos delitos e das penas", de Cesare de Bonesana, o Marquês de Beccaria. A par de uma série de limitações ao poder punitivo, preconizada por Beccaria, destaca-se, também, a idéia de proporcionalidade ${ }^{60}$. As idéias sustentadas por Beccaria não possuem o mérito da originalidade. Com efeito, boa parte das idéias que defende já havia sido apresentada por outros pensadores, ligados ao movimento iluminista. O mérito maior de sua obra reside na sistematização destas idéias e, sobretudo, em divulgá-las de forma consistente, acessível e clara. Em decorrência do êxito que obteve neste intento, a obra de Beccaria, "Dos delitos e das penas", tornou-se um verdadeiro estandarte deste movimento identificado com a humanização do Direito Penal.

A vitória do ideal liberal iluminista acarreta a consagração dos valores atinentes à humanização da intervenção penal, com a conseqüente proscrição da barbárie estatal, até então em vigor. Relevante destacar que esta humanização das sanções penais trouxe consigo o reforço à noção de proporcionalidade (em sua vertente necessidade), plasmada no art. VIII da Declaração dos Direitos do Homem e do Cidadão, de 1789: "a lei apenas deve cominar penas estrita e evidentemente necessárias, e ninguém pode ser punido senão em virtude de uma lei estabelecida e promulgada antes do delito, e aplicada em observância à lei" ${ }^{\prime 61}$.

Naturalmente, não se pode olvidar que a revolução burguesa, levada a cabo na França, não logrou êxito, de imediato, na implantação do rol de direitos cuja existência sustentara. Relevante salientar, ainda, a flagrante incoerência resultante dos discursos iluministas, centrados na idéia de fraternidade, e a implementação prática das diretrizes revolucionárias, com a conseqüente institucionalização do período histórico conhecido como "terror".

A despeito disto, não se pode deixar de anotar que os postulados da Revolução Francesa constituem um marco histórico de suma importância na consolidação de direitos e

\footnotetext{
${ }^{59}$ Também Montesquieu defendeu a idéia de proporção entre o delito e a pena, in verbis: "É um grande mal, entre nós, aplicar a mesma pena àquele que rouba em uma estrada e ao que rouba e assassina. É evidente que, para o bem da segurança pública, dever-se-ia estabelecer alguma diferença entre as penas" (MONTESQUIEU, Charles de Secondat. O espírito das leis. Tradução: Jean Melville. São Paulo: Martin Claret, 2002, p.103).

${ }^{60}$ Para Beccaria: "Não somente é interesse de todos que não se cometam delitos, como também que estes sejam mais raros proporcionalmente ao mal que causam à sociedade. Portanto, mais fortes devem ser os obstáculos que afastam os homens dos crimes, quando são contrários ao bem público e na medida dos impulsos que os levam a delinqüir. Deve haver, pois, proporção entre os delitos e as penas.” (BECCARIA, Cesare. Dos delitos e das penas. Tradução: J. Cretella Jr e Agnes Cretella. 2. ed. São Paulo: Revista dos Tribunais, 1999, p.37).

${ }^{61}$ Tradução livre de: "La Loi ne doit établir que des peines strictement et évidemment nécessaires, et nul ne peut être puni qu'en vertu d'une Loi établie et promulguée antérieurement au délit, et légalement appliquée."
} 
garantias até então relegados. A Revolução implementou a ruptura com a ordem vigente no Antigo Regime, pautado na concepção de poder político absoluto.

Por conta disto, os ideais que orientaram a eclosão da Revolução constituem, ainda hoje, paradigma observado pelas legislações de todo o mundo ocidental. Como cediço, as concepções revolucionárias estão calcadas em um ideário liberal, próprio do individualismo $^{62}$ burguês $^{63}$, hegemônico na fase pós-revolução. Como contraponto ao poder absoluto do Estado, importa, aos expoentes do movimento revolucionário, criar mecanismos de defesa do cidadão - e não mais o súdito, eis que, agora, titular de direitos - contra o arbítrio estatal. Assim surgem os chamados direitos de primeira geração - ou dimensão ${ }^{64}$, como prefere parcela da doutrina -, direitos civis e políticos. É certo que, posteriormente, surgem novas demandas e, portanto, novas lutas pela conquista de direitos, tais como os direitos econômicos, sociais e culturais, além dos direitos às gerações futuras, relativos à paz, informação, etc.

Contudo, no que importa, isto é, temas afetos à legitimação e limitação do poder de punir do Estado, não se pode perder de vista que este momento histórico, o advento dos chamados direitos de defesa, constitui a consagração de uma barreira instransponível para a persecução criminal. Apenas a título ilustrativo, pode-se fazer menção à Constituição

\footnotetext{
${ }^{62}$ A rigor, as críticas lançadas aos ideais da Revolução Francesa estão fundadas na concretização do direito de propriedade, na Declaração de 1789, como um direito inalienável e sagrado. À vista disto, os movimentos socialistas do século XIX identificaram a Revolução como uma revolução burguesa. Ressalta Bobbio que Marx acusou a Declaração de estar influenciada por uma concepção individualista da sociedade. Ao apreciar tal assertiva, Bobbio manifesta sua aquiescência, mas não encara o fato sob o mesmo viés negativo. Apreciando o contexto histórico, salienta o pensador italiano que, in verbis: "Decerto, o ponto de vista no qual se situa a Declaração para dar uma solução ao eterno problema das relações entre governantes e governados é o do indivíduo, do indivíduo singular, considerado como o titular do poder soberano, na medida em que, no hipotético estado de natureza pré-social, ainda não existe nenhum poder acima dele. O poder político, ou o poder dos indivíduos associados, vem depois" (BOBBIO, Norberto. A era dos direitos. Tradução: Carlos Nelson Coutinho. Rio de Janeiro: Elsevier, 2004, p.113). Mais que isto, Norberto Bobbio defende a concepção individualista, salientando que, in verbis: "É preciso desconfiar de quem defende uma concepção antiindividualista da sociedade. Através do antiindividualismo, passaram mais ou menos todas as doutrinas reacionárias. Burke dizia: 'Os indivíduos desaparecem como sombras; só a comunidade é fixa e estável.' De Maistre dizia: 'Submeter o governo à discussão individual significa destruí-lo.' Lammenais dizia: 'O individualismo, destruindo a idéia de obediência e de dever, destrói o poder e a lei.' Não seria muito difícil encontrar citações análogas na esquerda antidemocrática. Ao contrário não existe nenhuma Constituição democrática, a começar pela Constituição republicana da Itália, que não pressuponha a existência de indivíduos singulares que têm direitos enquanto tais. E como seria possível dizer que eles são 'invioláveis' se não houvesse o pressuposto de que, axiologicamente, o indivíduo é superior à sociedade de que faz parte?" (ob. cit. p.115-116).

${ }^{63}$ Outro ponto relevante que dá a tônica da hegemonia burguesa na diretriz do movimento revolucionário é a consagração do direito à propriedade como inalienável e sagrado, pela Declaração de 1789. Com efeito, em seu último artigo, dispõe a Declaração, in verbis: "A propriedade é um direito inviolável e sagrado, ninguém pode dela ser privado, salvo quando a necessidade pública, devidamente constatada, o exigir evidentemente, e sob a condição de uma justa e prévia indenização". Tradução livre de: "La propriété étant un droit inviolable et sacré, nul ne peut en être privé, si ce n'est lorsque la nécessité publique, légalement constatée, l'exige évidemment, et sous la condition d'une juste et préalable indemnité".

${ }^{64}$ SARLET, Ingo Wolfgang. A eficácia dos direitos fundamentais. 5 ed. Porto Alegre: Livraria do Advogado, 2005, p.43.
} 
francesa de $1848^{65}$, ainda fruto do processo revolucionário iniciado no século anterior, que consagrou dois direitos fundamentais de suma relevância, ao abolir a pena de morte em matéria política ${ }^{66}$ e a escravidão de todo o território francês ${ }^{67}$.

\subsection{Os reformadores, a humanização da pena privativa de liberdade e a sociedade disciplinar}

Ainda na esteira da sedimentação destes postulados relativos à limitação do poder de punir estatal e humanização da intervenção penal, cumpre consignar que este é momento histórico da consolidação da privação de liberdade como modalidade de pena ${ }^{68}$. Como já referido, até este momento, existia a prisão apenas como cautela, como custódia, mas não como pena. A prisão era, tão-somente, utilizada para instrumentalizar a aplicação da pena definitiva, comumente materializada em uma sanção consistente em suplícios corporais ou a própria pena capital, em suas diversas modalidades.

Alguns autores identificam a consolidação da pena de prisão com o advento do capitalismo e a sua conseqüente necessidade de regular o mercado de trabalho ${ }^{69}$. Uma vez passado em revista um breve histórico das mais variadas formas de aplicação de sanções penais, resta patente que a pena de privação de liberdade já constitui um significativo avanço no sentido de humanizar a intervenção do Estado por meio da tutela penal.

Conquanto isto seja um fato inconteste, deve-se destacar que as penas de privação de liberdade, ainda constituíam um flagelo cruel, sobretudo em face da periclitante situação em que se encontravam os estabelecimentos carcerários de então, ainda resultantes

\footnotetext{
${ }^{65}$ Sobre esta Constituição, afirma Fábio Konder Comparato: "A Constituição de 1848, por tudo isso, foi composta como uma obra de compromisso. De um lado, entre o liberalismo - claramente afirmado com a declaração preambular de redução gradual das despesas públicas e dos impostos - e o socialismo democrático. Compromisso, de outro lado, entre os valores conservadores - a Família, a Propriedade e a Ordem Pública, invocados com letra maiúscula no inciso IV do preâmbulo - e o progresso e a civilização (preâmbulo, inciso I)." (COMPARATO, Fábio Konder. A afirmação histórica dos direitos humanos. 3. ed. São Paulo: Saraiva, 2003, p.165).

${ }^{66}$ Art. 5. "La peine de mort est abolie en matière politique".

${ }^{67}$ Art. 6. "L'esclavage ne peut exister sur aucune terre française".

68 "O discurso e a prática assumidos, nessa nova realidade política, em favor dos direitos humanos são responsáveis pela alteração do panorama da coação estatal sobre os indivíduos. O reflexo sobre o direito penal é evidente, as formas cruéis de punição são paulatinamente rechaçadas e excluídas dos diplomas legais, iniciandose, segundo Foucault, a 'época da sobriedade punitiva', e a pena privativa de liberdade torna-se a principal sanção penal. As penas que se caracterizavam por serem corporais passaram a incidir sobre a alma - "o coração, o intelecto, a vontade, as disposições" (PRADO, Alessandra R. Mascarenhas. Regras de Tóquio e as penas restritivas de direitos: histórico e retratos do Brasil. MERCADANTE, Araminta; MAGALHÃES, José Carlos (org.). Reflexões sobre os 60 anos da ONU. Ijuí: Unijuí, 2005. p. 309-349).

${ }^{69}$ Neste sentido, cf. MELOSSI, Dario e PAVARINI, Massimo. Cárcere e fábrica: as origens do sistema penitenciário (século XVI-XIX). Tradução: Sérgio Lamarão. Rio de Janeiro: Revan: Instituto Carioca de Criminologia, 2006.
} 
dos calabouços medievais. À vista desta situação de fato, houve um considerável acréscimo no movimento tendente à humanização das instituições penitenciárias. Sendo certo que o objetivo maior dos pensadores que sustentavam estas teses era humanizar o cárcere, sem, contudo, aboli-lo, eles são considerados reformadores.

Dentre os reformadores, merecem referência alguns pensadores cujas idéias de tornaram emblemáticas, tais como John Howard, Jeremy Bentham e o próprio Cesare Beccaria.

Howard conheceu de perto as mazelas do cárcere, porquanto fora preso encarcerado, de início no Castelo de Brest e, depois, na prisão de Morlaix - quando retornava de uma viagem a Portugal, para onde havia se deslocado no afã de ajudar vítimas de um terremoto que recaíra sobre Lisboa, em $1755^{70}$. Tendo se dedicado com afinco às questões relativas às prisões, Howard se notabiliza, tanto por sua produção intelectual, quanto pela sua atuação prática, na medida em que teve oportunidade de aplicar, na prática, suas idéias, haja vista ter exercido os cargos de xerife e de alcaide do Condado de Bedford ${ }^{71}$. Dentre outras coisas, Howard defendia a adaptação das estruturas físicas das penitenciárias e a influência da religião - decorrência de sua formação religiosa, pois era calvinista -, como forma de fornecer subsídios morais aos condenados.

Outro pensador considerado um reformador, sobretudo no que diz respeito a questões atinentes ao cárcere, foi Jeremy Bentham. Absolutamente refratário à subsistência de castigos excessivos, marcados pela nota distintiva da crueldade e da desumanidade, Bentham, foi um grande defensor da teoria preventiva da pena, podendo o seu pensamento ser identificado com o utilitarismo. Bentham já chamava atenção para o fato de a prisão, para além de não coibir a reincidência, possuir, ela própria, natureza criminógena.

Bentham estabelecia a distinção entre prisão-cautela e prisão-pena, denominando a primeira de simples prisão e a segunda de prisão aflitiva ou penal. No que se refere à simples prisão, salienta que a severidade existente deve se adstringir àquela imprescindível à consecução do seu fim, que é a segurança, isto é, assegurar que o acautelado não consiga fugir. Nesta linha de raciocínio, qualquer rigor que extrapole estes estreitos limites da severidade será considerado um abuso, e, portanto, deve ser abolido ${ }^{72}$. No que tange à prisão aflitiva, ou penal, destaca que o seu grau de severidade deve obedecer a

\footnotetext{
${ }^{70}$ BITENCOURT, Cezar Roberto. Falência da pena de prisão: causas e alternativas. 3. ed. Saraiva: São Paulo, 2004, p.39.

${ }^{71}$ BITENCOURT, Cezar Roberto. Falência da pena de prisão: causas e alternativas. Ob. cit. p.39.

${ }^{72}$ BENTHAM, Jeremy. Ob. cit. p.77.
} 
critérios pessoais, além da natureza do crime. Demais disso, sustenta a prática do trabalho, por parte do preso $^{73}$.

Célebre contribuição de Bentham à questão da política carcerária diz respeito ao panótico. A idéia relativa ao panótico consistia, em apertada síntese, na construção de um monumento localizado no interior do cárcere e que possibilitasse aos administradores da penitenciária, e seus prepostos, vigiar constantemente os presos, ou, ao menos, passar esta impressão a eles.

Ao discorrer sobre o panótico, Bentham aponta três idéias fundamentais, a saber: (i) a construção de um edifício circular ou em forma de polígono "com seus quartos a roda de muitos andares, que tenha no centro um quarto para o inspetor poder ver todos os presos, ainda que eles não o vejam, e donde os possa fazer executar as ordens sem deixar o seu posto"74; (ii) a administração por contrato, idéia de acordo com a qual o particular deveria ficar encarregado de sustentar o preso, podendo, em contrapartida, auferir os lucros advindos do seu trabalho e, por fim, (iii) a responsabilidade do administrador, que seria um fiador e abonador da vida de cada um dos $\operatorname{presos}^{75}$.

Ao se debruçar, em estudo acurado, sobre o instituto do panótico, Michel Foucault utiliza a expressão panoptismo para designar a influência exercida por esta instituição na consolidação da "sociedade disciplinar", que substituiria a fase dos suplícios pela fase do controle, vigilância e disciplina nas relações de poder que grassam nos grupos sociais. Nas palavras de Foucault ${ }^{76}$, "o panoptismo ${ }^{77}$ é o princípio geral de uma nova 'anatomia política' cujo objeto e fim não são a relação de soberania, mas as relações de disciplina".

Ainda na linha de pensamento sustentada pelo pensador francês, não se pode confundir a disciplina com uma instituição, nem com nenhum tipo de aparelho; a disciplina é um tipo de poder, uma espécie de modalidade para o exercício do poder, que comporta um

\footnotetext{
${ }^{73}$ Idem, p.77.

${ }^{74}$ Idem, ibidem, p. 129.

${ }^{75}$ BENTHAM, Jeremy. Ob. cit., p.129.

${ }^{76}$ FOUCAULT, Michel. Vigiar e punir: nascimento da prisão. Tradução: Raquel Ramalhete. 32. ed. Petrópolis: Vozes, 1987, p.172.

${ }^{77}$ Sobre a influência do panótico, de Bentham, na construção desta perspectiva do panoptismo, salienta Foucault que aquele deve ser compreendido "como um modelo generalizável de funcionamento; uma maneira de definir as relações do poder com a vida cotidiana dos homens. Bentham sem dúvida o apresenta como uma instituição particular, nem fechada em si mesma. Muitas vezes se fez dele uma utopia do encarceramento perfeito. (...). Mas o Panóptico não deve ser compreendido como um edifício onírico: é o diagrama de um mecanismo de poder levado À sua forma ideal; seu funcionamento, abstraindo-se de qualquer obstáculo, resistência ou desgaste, pode ser bem representado como um puro sistema arquitetural e óptico: é na realidade uma figura de tecnologia política que se pode e se deve destacar de qualquer uso específico" (Idem, p.169-170).
} 
conjunto de técnicas, instrumentos, distintos níveis de aplicação e alvos ${ }^{78}$. Esta concepção de uma sociedade fundada no controle e na disciplina irradiara seus efeitos pelas mais variadas instituições existentes no grupo social, tais como as fábricas, as escolas, os quartéis e os hospitais $^{79}$, que reproduziriam a lógica vigente nas prisões.

No ponto que mais interessa a este trabalho, cabe trazer a lume a mudança de perspectiva experimentada pela justiça penal com o advento desta sociedade disciplinaria a que se refere Foucault. Ainda consoante as lições do pensador francês, esta lógica panóptica, transplantou o epicentro da justiça penal, até então fundada no corpo do condenado, para a disciplina infinita ${ }^{80}$. Este seria o ponto ideal da penalidade ${ }^{81}$. O suplício seria, tão-somente, o complemento de um processo marcado por uma persecução inquisitiva ${ }^{82}$, e ainda após a aplicação da pena, esta observação disciplinar se faria presente.

A importância conferida por Foucault ao estudo desta sociedade disciplinar é tamanha que chega a contrapor o poder disciplinar ao poder soberano ${ }^{83}$. De acordo com esta tese, a soberania permaneceria como discurso de poder, mas a efetivação prática deste poder seria levada a cabo por meio da disciplina, subjacente às relações sociais. Mais que isto, este poder disciplinar, aplicado em concreto, seria o efetivo poder, realidade fática que desvelaria a falácia do discurso formalista da igualdade de direitos perante a legislação. Em suma, enquanto a legislação alimentaria o discurso da igualdade perante a lei, as relações de poder em vigor na sociedade fundada na disciplina, estariam encarregadas da missão de negar, em concreto, este discurso.

\footnotetext{
${ }^{78}$ Idem, ibidem, p. 177.

${ }^{79}$ Idem, ibidem, p.187.

80 "O ponto extremo da justiça penal no Antigo Regime era o retalhamento infinito do corpo do regicida: manifestação do poder mais forte sobre o corpo do maior criminoso, cuja destruição total faz brilhar o crime em sua verdade. O ponto ideal da penalidade hoje seria a disciplina infinita: um interrogatório sem termo, um inquérito que se prolongasse sem limite numa observação minuciosa e cada vez mais analítica, um julgamento que seja ao mesmo tempo a medida permanente de um desvio em relação a uma norma inacessível e o movimento assintótico que obriga a encontrá-la no infinito" (idem, ibidem, p.187).

${ }^{81}$ Idem, ibidem, p. 187.

${ }^{82}$ FOUCAULT, Michel. Vigiar e punir: nascimento da prisão. Ob. cit. p.187.

83 "Quero dizer, mais precisamente, isto: eu creio que a normalização, as normalizações disciplinares, vêm cada vez mais esbarrar contra o sistema jurídico da soberania; cada vez mais nitidamente aparece a incompatibilidade de umas com o outro; cada vez mais é necessária uma espécie de discurso árbitro, uma espécie de poder e de saber que sua sacralização científicas tornaria neutros" (FOUCAULT, Michel. Em defesa da sociedade: curso no Collège de France (1975-1976). Tradução: Maria Ermantina Galvão. São Paulo: Martins Fontes, 1999, p.46).
} 